\title{
CHRYSALIS
}

\section{Body of evidence.}

\section{BY THOMAS BRODERICK}

\section{6th Precinct Official Police Report Case No: J-39453 \\ Date: September 22nd, 2076 \\ Reporting Officer: Harold Barnes \\ Prepared By: Detective Robert Jacla}

Detail of Event: On Thursday, September 17 th, 2076, at approximately 14:00, Central Dispatch received a call from Mrs Violet Jacobs, age 72, a resident of the 225 Balboa Avenue apartment complex. Mrs Jacobs reported that on the night of September 14th, she heard strange noises coming from her building's basement. She also explained that in the proceeding three days, a "horrible and foul" smell had filled the entire building.

Officer Harold Barnes arrived on the scene at 14:20. Searching the basement, he found human remains. Officer Barnes proceeded to call for backup. I arrived to begin the investigation at approximately 14:55.

The Investigation: In the southwest corner of the apartment's basement was approximately 10 kilograms of flesh and hair surrounded by a large pool of partially dried blood. The state of decay and presence of flies suggested that the flesh had been cast off the same evening Mrs Jacobs heard noises. Cuts along the flesh indicated clean, fast work, and that multiple individuals had been involved. I put in the call for forensics to take pictures and collect DNA samples. Before leaving, I informed the building superintendent of what we had found. I also provided him information on better securing his basement, and gave him my contact information in case he or any other residents remembered additional details about the event.

At 16:10 I received a match from the forensic DNA scan: Greg Osborne, 26 years old. I drove to Mr Osborne's last known address, 362 29th street. Mr Osborne's mother, Ms Danielle Osborne, greeted me at the door.

I stayed at Ms Osborne's home until 17:22. During my interview, Ms Osborne

DNATURE.COM Follow Futures: @ @NatureFutures f go.nature.com/mtoodm revealed that her son had undergone complete cyberization two years prior owing to a severe

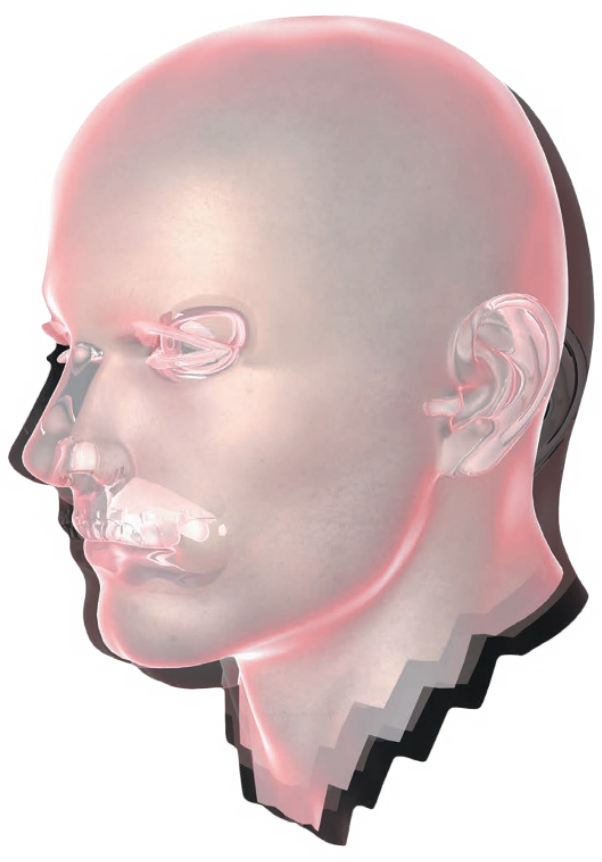

work accident. In January of this year, he received grafted flesh grown from preserved DNA samples.

"At first Greg was so happy," reported Ms Osborne. "He looked like his old self again. Then, after a few months, he changed. He would spend hours looking in the mirror. $\mathrm{He}$ was fired from his job, and had to move back home. I'd only see him come out of his room about once a week, if that. I can't imagine why he'd want to hurt himself."

After leaving Ms Osborne's home I proceeded to travel to the Aberline District slums. My contact there, a Cast Off who goes by the name 'Klein', informed me that a new individual (Klein: "He has not yet chosen his new name.") had joined their community on the morning of September 15th.

Klein provided me with specific details about Mr Osborne's ceremony. "He came to us willingly, Detective. He knew that Greg Osborne was really dead. The three of us that were there that night gave him every opportunity to walk away. He truly wanted it. I know it must look very violent to you, but for us it's birth, something beautiful. I hope there comes a day when we don't have to hide it anymore."

At the end of the interview I asked Klein to relay a message to the new individual: "Ms Osborne understands that she no longer has a son, but she would like to know that the person he became is all right." Klein said that he couldn't make any promises, but that he would try.

Summary: The remains of Mr Greg Osborne were destroyed by the city coroner and disposed of as medical waste. His death certificate was issued to Ms Osborne. I recommend that the case be closed, to be reopened only if the Cast Off formally known as Greg Osborne comes forward to testify against those who performed his ceremony. Otherwise, a crime did not occur.

Notes: This case represents the 16th 'casting off' in New York City since August 1st of this year, and the 5 th that I have personally investigated in that time. These ceremonies are becoming more frequent, and I hope that either the lawmakers or mental health professionals would offer legal guidance on how to aid these clearly disturbed individuals.

Detective Jacla read over the report on his terminal. With a swipe of his finger he sent it along to the lieutenant for final approval. He got up from his desk, and after stretching, went to the bathroom to splash some water on his face. Drying himself off with a few paper towels, he stared into the mirror.

Jacla unconsciously pinched his chin, a place where at the age of nine he had scarred himself falling off his bike. Yet there was no scar. A static tremor ran down his spine. Just beyond that little bit of warm skin and blood was cold polyurethane, metal and circuitry. It didn't creak, buzz or hum, but it was there. Every look in the mirror was a reminder that it was there. Every idle moment was a reminder that it was there. Wouldn't it just be better if ... Jacla blinked hard, and walked out of the bathroom as fast as he could.

As he left the police station a few minutes later, Detective Jacla avoided looking at any more mirrors, lest he begin to wonder who, or what, really stared back.

Thomas Broderick is a freelance writer living in northern California. Since 2012, his short stories have appeared in a variety of US and UK publications. You can contact Thomas on Twitter@brod_in_the_am. 